\title{
KARAKTERISTIK, MOTIVASI DAN NIAT BERKUNJUNG WISATAWAN MANCANEGARA KE DESA VISESA UBUD RESORT AND VILLA
}

\author{
I Made Surya Adi Dwi Negara ${ }^{1}$, LGLK. Dewi ${ }^{2}$, \\ Putu Agus Wikanantha Sagita ${ }^{3}$ \\ ${ }^{1}$ Email: suryaadidwinegara@gmail.com \\ Program Studi Industri Perjalanan Wisata, Fakultas Pariwisata, Universitas Udayana \\ 2Email: leli_ipw@unud.ac.id \\ Program Studi Industri Perjalanan Wisata, Fakultas Pariwisata, Universitas Udayana \\ ${ }^{3}$ Email: wika.fpar@gmail.com \\ Program Studi Industri Perjalanan Wisata, Fakultas Pariwisata, Universitas Udayana
}

\begin{abstract}
Desa Visesa Ubud Resort and Villa is a resort with a concept of returning to nature that provides various activities for tourists who stay. The purpose of this study was to determine the characteristics, motivation and intention of visiting foreign tourists to do activities in Visesa Village, Ubud Resort and Villa. The technique of determining the sample using purposive sampling with 100 respondents. The data analysis technique used in this study is the descriptive statistical technique. The results showed that the characteristics of foreign tourists who are active in the Village Visesa Ubud Resort and Villa are grouped into tourist descriptors and trip descriptors. The results of the motivation of foreign tourists who move in the Village of Visesa Ubud Resort and Villa based on the sub variable push factor motivation the results show that the highest driving factor is an indicator of leisure time. Based on the sub variable pull factor motivation, the results show that the highest pull factor is an indicator of amenities. The results of the variable intention to revisit tourists who are active in the Village Visesa Ubud Resort and Villa show that the highest indicator influencing tourist intentions is a complaining indicator or no complaints and overall agreed to visit the Village Visesa Ubud Resort and Villa as evidenced by tourists do not give criticism or complaints to the management or staff in Desa Visesa Ubud Resort and Villa.
\end{abstract}

\begin{abstract}
Abstrak: Desa Visesa Ubud Resort and Villa adalah sebuah resort dengan konsep kembali ke alam yang menyediakan berbagai aktivitas bagi wisatawan yang menginap. Tujuan dari penelitian ini untuk mengetahui karakteristik, motivasi dan niat berkunjung wisatawan mancanegara untuk beraktivitas di Desa Visesa Ubud Resort and Villa. Teknik penentuan sampel menggunakan purposive sampling dengan 100 orang responden. Teknik analisis data yang digunakan pada penelitian ini adalah teknik statistika deskriptif. Hasil penelitian menunjukkan bahwa karakteristik wisatawan mancanegara yang beraktivitas di Desa Visesa Ubud Resort and Villa dikelompokkan menjadi tourist descriptor dan trip descriptor. Hasil dari Motivasi wisatawan mancanegara yang beraktivitas di Desa Visesa Ubud Resort and Villa berdasarkan sub variabel push factor motivation diperoleh hasil bahwa faktor pendorong tertinggi adalah indikator leisure time. Berdasarkan sub variabel pull factor motivation diporeleh hasil bahwa faktor penarik tertinggi adalah indikator amenities. Hasil dari variabel niat berkunjung kembali wisatawan yang beraktivitas di Desa Visesa Ubud Resort and Villa menunjukkan bahwa indikator tertinggi yang memperngaruhi niat wisatawan adalah indikator complaining atau tidak terdapat keluhan dan secara keseluruhan setuju untuk berkunjung kembali ke Desa Visesa Ubud Resort and Villa.
\end{abstract}

Keywords: characteristic, motivation, intention, foreign tourist, activities. 


\section{PENDAHULUAN}

Bali sebagai Pulau yang mengalami perkembangan pariwisata yang pesat telah memperoleh penghargaan dari Tripadvisor memberikan predikat bali sebagai "The Best Destination in The World" pada tahun 2017. Sebagai destinasi terbaik dunia, tentu Bali dikunjungi oleh wisatawan dengan karakteristik maupun demografis wisatawan yang berbeda dan setiap harinya mengalami perubahan yang disebabkan oleh kemajuan teknologi yang membuat biaya perjalanan menjadi lebih murah dan informasi lebih mudah didapat.

Saat ini wisatawan mancanegara yang berkunjung ke Bali tidak hanya bertujuan untuk menikmati atraksi wisata yang dimiliki, tetapi terdapat motivasi lain yang mendorong mereka untuk berwisata ke Bali yaitu untuk lebih bisa berinteraksi dengan masyarakat lokal agar dapat mengetahui aktivitas yang dilakukan sehari-hari. Motivasi wisatawan adalah faktor pendorong dari dalam diri yang memotivasi seseorang untuk melakukan perjalanan wisata, karena adanya keinginan serta adanya daya tarik yang ditawarkan oleh obyek wisata yang akan dikunjunginya. Menurut Chafid Fandeli (1995) motivasi yang mendorong seseorang untuk melakukan perjalanan wisata dapat dikelompokkan menjadi empat kelompok besar sebagai berikut :

1. Motivasi fisik (physical motivation) antara lain menyegarkan kembali badan dan jiwa, istirahat karena kesehatan, olahraga, rekreasi: bersenang-senang, berpacaran, berbelanja.

2. Motivasi kebudayaan (cultural motivation) antara lain Ingin mengetahui budaya, seni, musik, arsitektur, sejarah negara lain, peristiwa penting (olahraga, pekan perdagangan, peristiwa lain bertaraf nasional/internasional.

3. Motivasi individu (interpersonal motivation) antara lain mengunjungi keluarga, teman atau mencari teman baru, perjalanan bersenang-senang, kunjungan spiritual, mencari pengalaman baru pada lingkungan baru (fisik dan sosial).

4. Motivasi prestise dan status (status and prestise motivation) antara lain penyaluran hobi, melanjutkan belajar, pertemuan untuk menjalin hubungan personal, menghadiri konferensi dan seminar.

Menurut Spilanne (2002) daya Tarik wisata adalah hal-hal yang menarik perhatian wisatawan yang dimiliki oleh suatu daerah tujuan wisata. Menurut Mulyo (2005) faktor-faktor yang dapat membentuk daya tarik dalam suatu tempat wisata antara lain : Atraksi wisata, yaitu daya tarik wisata utama suatu obyek wisata yang mempengaruhi minat pengunjung untuk menikmatinya. Transportasi, yaitu sarana pencapaian ke tempat daerah tujuan wisata, hal ini berkaitan dengan kemudahan pencapaian dan tingkat aksesibilitas. Akomodasi, yaitu pendukung kegiatan pariwisata yang bertujuan memenuhi kebutuhan wisatawan untuk mendapatkan kenyamanan dan kepuasan. Fasilitas penunjang, meliputi fasilitas umum seperti telepon umum, mushola/masjid, toilet, dan fasilitas lain. Prasarana, seperti penerangan, air bersih, dan lain-lain.

Dalam suatu daya tarik wisata, atraksi wisata merupakan salah satu komponen penting. Atraksi wisata merupakan salah satu faktor inti tarikan pergerakan wisatawan menuju daerah tujuan wisata. Menurut Middelton (2001) terdapat dua fungsi dari atraksi yaitu sebagai penarik wisatawan dalam pariwisata serta sebagai salah satu produk utama pariwisata dan faktor tujuan utama kedatangan pengunjung. Dengan pernyataan di atas, menurut Edward Inskeep (1991) faktor yang menentukan dalam berkembangnya sebuah destinasi antara lain, atraksi, amenitas dan aksesibilitas.

Daya tarik wisata buatan adalah segala sesuatu yang berasal dari karya manusia dan dapat di jadikan sebagai 
objek wisata seperti benda - benda sejarah kebudayaan religi, serta tata cara manusia. Untuk dapat disebut sebagai suatu daya tarik wisata buatan maka suatu daya tarik tersebut harus memiliki atraksi wisata yang merupakan buatan dari manusia. Salah satu daya tarik wisata buatan yang pada saat ini ramai dikunjungi wisatawan baik domestik maupun mancanegara adalah Desa Visesa Ubud Resort and Villa yang sudah memenuhi faktor-faktor pembentuk suatu daya tarik wisata yang terdiri dari atraksi wisata, aksesibilitas, akomodasi, dan fasilitas penunjang lainnya.

Desa Visesa Ubud Resort and Villa merupakan sebuah Resort yang terletak di kawasan ubud centre. Resort di Desa Visesa Ubud Resort and Villa ini berbeda dengan tempat lainnya karena Desa Visesa Ubud Resort and Villa tidak seperti Resort lainnya karena dikemas dalam suatu bentuk desa wisata yang sengaja dibuat oleh pengelolanya agar wisatawan yang menginap dapat merasakan kehidupan desa yang asri, tenang dan sejuk serta melakukan aktivitas seperti masyarakat lokal ubud. Meskipun Desa Visesa Ubud Resort and Villa disebut sebagai sebuah Resort, akan tetapi di dalamnya terdapat suatu atraksi aktivitas wisata yang berbeda dengan Resort lainnya karena atraksi aktivitas wisata yang disediakan jumlahnya banyak danberagama dan hal tersebut tidak ditemukan di desa wisata lainnya. Atraksi aktivitas wisata yang disediakan adalah aktivitas yang mencerminkan gaya hidup asli dan tradisi warisan masyarakat lokal seperti : mengembala bebek, bercocok tanam secara tradisional, bertani, membajak sawah menggunakan sapi, dan aktivitas tradisional lainnya seperti yang dilakukan oleh masyarakat asli bali pada umumnya.

Menuju Desa Visesa Ubud Resort and Villa, jalan yang akan dilalui oleh wisatawan adalah jalan aspal dan dengan jarak tempuh yang cukup dekat sehingga memudahkan wisatawan untuk mencapai daya tarik wisata tersebut. Desa ini juga dilengkapi dengan akomodasi seperti Resort, private villa dengan private pool, dan suite room dengan gaya khas Bali serta dilengkapi dengan Fasilitas penunjang lainnya seperti Spa dan terapi kesehatan bagi wisatawan secara tradisional. Dengan banyaknya atraksi wisata yang disediakan maka Desa Visesa Ubud Resort and Villa sebagai daya tarik wisata buatan lebih menonjolkan atraksi wisata budaya dan atraksi wisata way of life.

Jumlah wisatawan yang berkunjung Desa Visesa Ubud Resort and Villa setiap tahunnya mengalami peningkatan. Untuk itu perlu dilakukan suatu penelitian tentang karakteristik, motivasi, dan niat wisatawan mancanegara berkunjung dan melakukan aktivitas wisata di Desa Visesa Ubud Resort and Villa karena Desa Visesa Ubud Resort and Villa merupakan sebuah Resort baru yang berada di Kawasan Ubud dan merupakan satu-satunya resort yang menyediakan atraksi aktivitas wisata tradisional masyarakat lokal ubud bagi wisatawan yang menginap di resort sehingga setelah megetahui bagaimana karakteristik dan apa motivasi wisatawan yang berkunjung untuk beraktivitas maka akan diketahui apakah wisatawan memiliki niat berkunjung kembali untuk beraktivitas dan apa yang menjadi penyebab wisatawan memiliki niat berkunjung kembali tersebut. Selain itu mengetahui karakteristik, motivasi dan niat wisatawan mancanegara sangat diperlukan untuk mengetahui apa yang perlu dilakukan perbaikannya kedepannya oleh pihak pengelola Desa Visesa Ubud Resort and Villa selaku penyedia jasa dalam bidang pariwisata mengingat Bali merupakan pulau yang sampai saat ini masih menjadi pulau yang ramai dikunjungi oleh wisatawan mancanegara sehingga kedepannya perlu dilakukan inovasi dalam bidang pariwisata terutama dalam daya tarik maupun atraksi wisatanya, mapun dalam akomodasi yang disediakan bagi wisatawan. 


\section{METODE}

Studi ini dilakukan untuk mengetahui karakteristik, motivasi, dan niat berkunjung wisatawan mancanegara untuk berktivitas di Desa Visesa Ubud Resort and Villa. Variabel yang digunakan antara lain variabel karakteristik yang dibagi menjadi 2 sub variabel yaitu tourist descriptor yang terdiri dari indikator umur, jenis kelamin, pekerjaan, daerah asal, pendidikan, dan status perkawinan serta sub variabel trip descriptor dengan indikator sumber informasi, jumlah kunjungan ke Bali, jenis akomodasi, lama tinggal di Bali, alasan memilih daya tarik wisata yang dikunjungi, teman berkunjung, pengatur perjalanan wisata (Seaton dan Bennet, 1996). Variabel Motivasi yang dibagi menjadi sub variable push factor dengan indikator escape, relaxation, social interaction, education opportunity, dan leisure time (Pitana, 2005) . Sub variabel pull factor dengan indikator cuaca/iklim, transportasi/akses, atraksi wisata, amenities, dan lingkungan hidup (Wibisono, 2013). Variabel niat dengan indikator loyality to the company, positive word of the mouth, properency to switch, dan complaining (Liu Furrer, dan Sudharshan, 2001). Teknik pengumpulan data dilakukan dengan observasi, wawancara, kuesioner, studi kepustakaan, dan dokumentasi. Teknik pengambilan sampel dilakukan dengan purposive sampling. Penentuan jumlah sampel dilakukan dengan menggunakan rumus Slovin yaitu dengan menentukan taraf kesalahan sebesar $0.10 \%$ sehingga besar sampel berjumlah 100 orang (Sugiyono, 2011). Teknik Analisis data dilakukan dengan teknik analisis statistik deskriptif. Salah satu ukuran pemusatan data yang biasa digunakan pada teknik analisis ini adalah mean (Fauzi, 2009).

\section{HASIL DAN PEMBAHASAN \\ Desa Visesa Ubud Resort and Villa}

Desa Visesa Ubud Resort and Villa

Ubud merupakan sebuah Resort yang memiliki konsep yang berbeda dengan Resort lainnya yang ada di Bali. Terletak di Jalan Suweta, Banjar Bentuyung Sakti, Kelurahan Ubud, Kabupaten Gianyar yang berlokasi 1,5 kilometer dari Central Ubud. Desa ini merupakan desa yang terletak di tengah sawah dengan luas 6,5 hektare dengan berbagai fasilitas penunjangnya seperti 66 Resort, 66 Pool Villas dan 40 Suites berkelas Resort bintang 5 yang bernuansa tradisional Bali dan memiliki pesona unik. Empat restoran, kolam renang besar, dan spa menawarkan ritual kecantikan dan terapi kesehatan tradisional bergaya bangsawan kerajaan di Bali, selain itu wisatawan akan mendapatkan sarapan dengan berbagai fasilitas yang ada di dalam kamarnya seperti kolam renang pribadi disetiap kamarnya, minibar dengan berbagai minuman yang telah disediakan untuk wisatawan, dan wisatawan dapat melakukan kegiatan yang disediakan oleh Visesa Resort and Villa, dan kegiatan tersebut merupakan kegiatan rutin yang dilakukan setiap harinya sepeti : bersepeda mengelilingi desa, mengelilingi area persawahan, membuat gebogan, kursus dan praktek pada area persawahan untuk menanam padi, belajar menari dan memainkan musik khas bali, dan melakukan yoga.

\section{Karakteristik Wisatawan}

Karakteristik wisatawan dalam penelitian ini dibagi menjadi 2 sub variabel yaitu tourist descriptor dan trip descriptor, dari penyebaran kuisioner terhadap 100 responden dapat diketahui bahwa karakteristik wisatawan berdasarkan tourist descriptor berasal dari Australia terdapat 25 responden atau (25\%) dengan pembagian umur antara 1625 tahun terdapat 46 responden atau $(46 \%)$, berjenis kelamin perempuan terdapat 51 responden atau (51\%), bekerja di sektor swasta terdapat 31 responden atau (31\%), berpendidikan terakhir Sarjana terdapat 59 responden atau (59\%), dengan status kawin terdapat 80 responden atau 
$(80 \%)$ dan bertujuan untuk liburan di Desa Visesa Resort and Villa tedapat 100 responden atau (100\%). Karakteristik wisatawan berdasarkan trip descriptor wisatawan yang pertama kali ke Visesa Resort and Villa terdapat 90 responden atau (90\%), tinggal lebih dari 6 hari terdapat 79 responden atau $(79 \%)$ karena wisatawan mancanegara didominasi oleh wisatawan asal Australia dan bekerja di sektor swasta sehingga mereka memiliki waktu cuti untuk liburan, memperoleh informasi dari media sosial terdapat 71 responden atau $(71 \%)$, sedangkan dari website perusahaan sebesar 20 responden atau $(20 \%)$ hal tersebut karena media sosial memberikan informasi terkini dibandingkan dengan website perusahaan yang harus diperbaharui sistemnya agar dapat memberikan informasi yang lebih baru, wisatawan memilih jenis akomodasi private Villa terdapat 80 responden atau (80\%), dengan alasan ke Visesa Resort and Villa karena memiliki atraksi wisata yang unik terdapat 38 responden atau $(38 \%)$, berkunjung dengan teman terdapat 51 responden atau (51\%) dan yang mengatur perjalanan adalah diri sendiri terdapat 80 responden atau $(80 \%)$ sedangkan agen perjalanan terdapat 0 responden atau $(0 \%)$ hal tersebut karena agen perjalanan belum membuka kerjasama dengan Desa Visesa Ubud Resort and Villa dalam menjual produk wisata yang berupa aktivitas wisata.

\section{Motivasi Wisatawan}

Motivasi wisatawan mancanegara yang beraktivitas di DesaVisesa Ubud dalam penelitian ini menggunakan teori motivasi dari Maslow (1943) yang disebut dengan push and pull motivation. Push Factor Motivation wisatawan mancanegara beraktivitas di Desa Visesa Ubud Resort and Villa dengan indikator leisure time yang dalam peneltiaian ini berarti waktu bebas yang dimiliki untuk membebaskan diri dari beban kerja, terbebas dari kewajiban-kewajiban yang ada serta terbebas dari kegiatan tidak menyenangkan yang dilakukan setiap harinya. Leisure time mempunyai skor tertinggi dari 5 indikator yang terdapat dalam sub variabel Push Factor Motivation yaitu dengan perolehan skor 459 dan rata-rata 4,59 pada kategori sikap sangat setuju. Hal tersebut berkaitan dengan wisatawan mancanegara yang beraktivitas di Desa Visesa Ubud Resort and Villa di dominasi oleh wisatawan yang berasal dari Australia dan bekerja pada sektor swasta yang bertujuan untuk liburan ke Bali dengan waktu kunjungan selama lebih dari 6 hari karena pada sektor swasta memberikan waktu cuti untuk berlibur bagi karyawannya. Selanjutnya indikator tertinggi kedua adalah indikator relaxation atau untuk mendapatkan penyegaran dengan perolehan skor 431 dengan ratarata 4,31 yaitu pada kategori sikap setuju, artinya sebagian besar wisatawan mancanegara beraktivitas di Desa Visesa Ubud Resort and Villa karena ingin mendapatkan penyegaran atau relaxation. Indikator escape atau melepaskan diri dari lingkungan yang menjenuhkan mempunyai perolehan skor tertinggi ketiga setelah indikator relaxation atau untuk mendapatkan penyegaran dengan perolehan skor 401, rata-rata 4,01. Skor tersebut dikategorikan dalam kategori setuju. Disini wisatawan mancanegara setuju dengan escape atau melepaskan diri dari lingkungan yang menjenuhkan karena menurut penelitian wisatawan yang melakukan aktivitas di Desa Visesa Ubud Resort and Villa ingin menikmati perbedaan rutinitas dan perbedaan suasana sehari-hari. Indikator tertinggi keempat setelah escape atau melepaskan diri dari lingkungan yang menjenuhkan adalah indikator educational opportunity atau keinginan untuk mengetahui sesuatu yang baru dengan total skor 400, rata-rata 4,00 dengan nilai sikap setuju. Dalam hal ini wisatawan setuju untuk beraktivitas di Desa Visesa Ubud Resort and Villa karena Desa Visesa Ubud Resort and Villa memiliki berbagai jenis atraksi wisata dan fasilitas yang sebelumnya tidak diketahui 
oleh wisatawan sehingga wisatawan setelah beraktivitas di Desa Visesa Ubud Resort and Villa akan mendapatkan pengetahuan baru seperti dalam hal menanam padi, bercocok tanam, mengembala bebek, membersihkan sapi, maupun membuat sesajen upacara dalam masyarakat hindu. Indikator yang menduduki posisi terakir adalah indikator social interaction atau interaksi sosial dengan total skor 390, rata-rata 3,90 dan dengan skala sikap setuju. Alasan wisatawan mancanegara setuju dengan indikator social interaction karena wisatawan ingin melakukan berbagai interaksi sosial dengan masyarakat lokal Visesa Resort and Villa.

Pull Factor Motivation wisatawan mancanegara beraktivitas di Desa Visesa Ubud Resort and Villa dengan indikator amenities atau perlengkapan sarana dan prasarana mempunyai skor tertinggi dengan perolehan skor 440 dan rata-rata 4,40 pada kategori sikap sangat setuju. Hal tersebut dikarenakan oleh Desa Visesa Ubud Resort and Villa merupakan sebuah Resort bintang lima yang menyediakan aktivitas khas bali bagi wisatawan yang menginap, sehingga wisatawan yang menginap di Desa Visesa didominasi oleh wisatawan yang memilih akomodasi jenis Private Villa atau Villa yang bersifat pribadi sehingga sarana dan prasarana yang disediakan dapat digunakan secara pribadi, selain itu wisatawan dapat menikmati sarana dan prasarana secara pribadi. Di Desa Visesa Ubud Resort dan Villa juga terdapat sarana dan prasarana lainnya yang digunakan untuk menunjang kenyamanan wisatawan seperti adanya ruang tunggu yang nyaman, toilet umum yang bersih, dan adanya restaurant yang bersih dengan berbagai menu masakan khas Bali dengan bahan makanan yang bisa langsung dipetik oleh wisatawan dari kebun yang terdapat di Visesa Resort and Villa. Indikator tertinggi kedua adalah indikator cuaca atau iklim dengan perolehan skor 411 dengan rata-rata 4,11 yaitu pada kategori sikap setuju, artinya sebagian besar wisatawan mancanegara beraktivitas di Desa Visesa Ubud Resort and Villa karena ingin merasakan cuaca atau iklim yang berbeda dengan negara asalnya. Alasan mereka setuju dengan indikator cuaca atau iklim sebagai indikator terbesar kedua karena mayoritas wisatawan yang beraktivitas di Desa Visesa Ubud Resort and Villa berasal dari Negara Australia. Pada saat musim dingin atau musim salju yang berlangsung dari bulan Juni sampai dengan bulan Agustus wisatawan akan melakukan kunjungannya ke Bali dan pada saat bulan-bulan tersebut di Bali akan mengalami high season. Indikator atraksi wisata mempunyai perolehan skor tertinggi ketiga setelah indikator cuaca/iklim dengan perolehan skor 400, rata-rata 4,00. Skor tersebut dikategorikan dalam kategori setuju. Disini wisatawan mancanegara setuju dengan atraksi wisata yang ada di Desa Visesa Ubud Resort and Villa dimana atraksi wisata memiliki keunikan dengan atraksi wisata di Desa lain. Atraksi wisata yang disediakan pada Desa Visesa Ubud Resort and Villa terdiri dari atraksi budaya, atraksi alam, dan atraksi buatan. Indikator tertinggi keempat setelah atraksi wisata adalah indikator transportasi dan akses dengan total skor 383, rata-rata 3,83 dengan nilai sikap setuju. Dalam hal ini wisatawan setuju untuk beraktivitas di Desa Visesa Ubud Resort and Villa karena akses jalan menuju Desa Visesa Ubud Resort and Villa sudah melalui jalan beraspal yang lengkap dengan penunjuk arah maupun dapat diakses melalui google maps dan bisa dilalui dengan jenis transportasi mobil pribadi, bus, motor dan transportasi lainnya. Indikator yang menduduki posisi terahkir adalah indikator lingkungan hidup dengan total skor 369, rata-rata 3,69 dan dengan skala sikap setuju. Meskipun mendapatkan skala sikap setuju, akan tetapi indikator lingkungan hidup menduduki posisi terendah dari indikator lainnya karena tidak semua wisatawan yang beraktivitas di Desa Visesa Ubud Resort and Villa tertarik 
dengan kegiatan ekowisata yang dilakukan ditempat ini karena mereka lebih tertarik dengan aktivitas kebudayaan yang disediakan.

\section{Niat Wisatawan}

Niat wisatawan yang dimaksud merupakan hubungan yang positif antara kepuasan, perilaku pembelian, dan kinerja bisnis. Wisatawan yang merasa terpenuhi tingkat harapan sebelum pembelian akan meningkatkan komitmen pembelian seperti niat untuk membeli atau dalam penelitian ini dapat disebut sebagai niat berkunjung kembali wisatawan mancanegara untuk beraktivitas di Desa Visesa Ubud Resort dan Villa Niat wisatawan mancanegara beraktivitas di Desa Visesa Ubud Resort and Villa dengan indikator complaining atau tidak memiliki keluhan mempunyai skor tertinggi dari 4 indikator yang terdapat dalam variabel Niat dengan perolehan skor 430 dan rata-rata 4,30 pada kategori sikap setuju dengan pengertian wisatawan tersebut setuju untuk kembali ke Desa Visesa Ubud Resort and Villa karena tidak memiliki keluhan kepada Visesa Resort and Villa. Hal tersebut terlihat dari sedikitnya wisatawan yang mengisi kritik dan saran kepada Visesa Resort and Villa. Indikator tertinggi kedua adalah indikator propencity to switch atau tidak mudah beralih ke tempat lain dengan perolehan skor 428 dengan rata-rata 4,28 yaitu pada kategori sikap setuju, artinya sebagian besar wisatawan akan berkunjung kembali dan tidak akan beralih dari Desa Visesa Ubud Resort and Villa ke Desa Wisata lainnya karena wisatawan sudah merasa nyaman dengan segala sesuatu yang disediakan oleh pihak manajemen di Desa Visesa Ubud Resort and Villa yang belum ditentu ditemukan di Desa lainnya. Indikator loyality to the company atau mau membayar lebih mempunyai perolehan skor tertinggi ketiga dengan perolehan skor 400, rata-rata 4,00. Skor tersebut dikategorikan dalam kategori setuju. Alasan wisatawan setuju untuk indikator berani membayar lebih karena wisatawan merasa puas dengan pelayanan ketika berada di Visesa Resort and Villa. Indikator yang menempati posisi terakhir adalah indikator Positive word of the mouth atau memberikan informasi dengan total skor 383, rata-rata 3,83, dan dengan skala sikap setuju. Setuju dalam artian wisatawan yang sudah pernah beraktivitas di Desa Visesa Ubud Resort and Villa akan selalu memberikan informasi mengenai Desa Visesa Ubud Resort dan Villa kepada teman atau keluarga mereka serta membagikan pengalamannya selama beraktivitas di Desa Visesa Ubud Resort and Villa sehingga nantinya akan menarik wisatawan lain untuk berkunjung kembali ke DesaVisesa Ubud Resort and Villa.

\section{SIMPULAN DAN SARAN \\ Simpulan}

Karakteristik wisatawan mancanegara yang beraktivitas di Desa Visesa resort and Villa berdasarkan tourist descriptor diperoleh hasil bahwa wisatawan mancanegara yang beraktivitas banyak didominasi oleh wisatawan asal Australia yaitu $25 \%$, dengan pembagian umur antara 16-25 tahun sebesar 46\%, berjenis kelamin perempuan dengan presentase $51 \%$, bekerja di sektor swasta dengan presentase $31 \%$, berpendidikan terakhir Sarjana sebanyak 59\%, dengan didominasi status kawin sebesar $80 \%$ dan bertujuan untuk liburan di Visesa resort and Villa sebesar 90\%. Berdasarkan trip descriptor diperoleh hasil bahwa wisatawan mancanegara yang beraktivitas banyak didominasi oleh wisatawan yang pertama kali ke Visesa resort and Villa yaitu sebesar $90 \%$, dengan lama kunjungan lebih dari 6 hari dengan presentase $79 \%$ karena wisatawan mancanegara didominasi oleh wisatawan asal Australia dan bekerja di sektor swasta sehingga mereka memiliki waktu cuti untuk liburan, memperoleh informasi dari media sosial sebanyak $71 \%$ karena media sosial memberikan informasi terkini dibandingkan dengan website perusahaan yang harus diperbaharui sistemnya agar 
dapat memberikan informasi yang lebih baru, dengan menggunakan jenis akomodasi private Villa sebesar $80 \%$, dengan alasan ke Desa Visesa resort and Villa karena memiliki atraksi wisata yang unik yaitu sebesar 39\%, berkunjung dengan teman dengan presentase $51 \%$ dan yang mengatur perjalanan adalah diri sendiri dengan presentase $80 \%$ karena agen perjalanan belum membuka kerjasama dengan Desa Visesa Ubud Resort and Villa dalam menjual produk wisata yang berupa aktivitas wisata.

Motivasi wisatawan mancanegara yang beraktivitas di Desa Visesa resort and Villa berdasarkan sub variabel push factor motivation diperoleh total skor sebesar 2018, rata-rata 4,16 dan kategori sikap setuju dengan skor per indikator sebagai berikut : leisure time dengan skor likert 4,59 dan kategori sikap sangat setuju, relaxation dengan skor likert 4,31 dan kategori sikap setuju, escape dengan skor liker 4,01 dan kategori sikap setuju, education opportunity dengan skor likert 4,00 dan kategori sikap setuju, dan social interaction dengan skor likert 3,90 dan kategori sikap setuju.

Berdasarkan pull factor motivation total skor sebesar 2003, rata-rata 4,00 dan kategori sikap setuju dengan skor per indikator sebagai berikut : amenities dengan skor likert 4,40 dan kategori sikap sangat setuju, cuaca/iklim dengan skor likert 4,11 dan kategori sikap setuju, atraksi wisata dengan skor liker 4,00 dan kategori sikap setuju, transportasi/akses dengan skor likert 3,83 dan kategori sikap setuju, dan lingkungan hidup dengan skor likert 3,69 dan kategori sikap setuju.

Niat wisatawan beraktivitas di Desa Visesa Resort and Villa memperoleh skor sebesar 1461 dengan skor likert 4,10 dan kategori sikap setuju dimana wisatawan secara keseluruhan setuju untuk berkunjung kembali ke Desa Visesa Resort and Villa hal tersebut dibuktikan dengan wisatawan tidak memberikan kritikan atau complain dengan skor likert 4,30 dan kategori sikap setuju, wisatawan tidak mudah berpindah ke tempat lain atau propencity to switch dengan skor likert 4,30 dan kategori sikap setuju, wisatawan berani membayar lebih atau loyality to the company dengan skor likert 4,00 dan kategori sikap setuju dan mau merekomendasikan dan memberikan informasi kepada orang lain mengenai Desa Visesa Resort and Villa atau positive word of the mouth dengan skor likert 3,83 dan kategori sikap setuju.

\section{Saran}

Bagi pihak pengelola atau pekerja di Desa Visesa Resort and Villa agar selalu menjaga dan meningkatkan kualitas pelayanan seperti staf Desa Visesa Resort and Villa harus lebih berhati-hati dalam membantu wisatawan, lebih meningkatkan kebersihan kamar karena Visesa Resort and Villa memiliki konsep kamar yang terbuka dan menyatu dengan alam, lebih meningkatkan kualitas makanan yang akan diberikan kepada wisatawan. Dengan meningkatkan kualitas pelayanan, wisatawan akan selalu merasa nyaman dan termotivasi untuk kembali beraktivitas di Visesa Resort and Villa pada saat berlibur di Bali. Selain itu Desa Visesa Resort and Villa juga harus tetap berinovasi atau menciptakan sesuatu yang lebih baru dan lebih unik lagi dengan tidak menghilangkan unsur kebudayaan. Inovasi tersebut dapat dilakukan pada saat membangun akomodasi baru bagi wisatawan yang lebih modern dengan tidak meninggalkan kebudayaan, dalam memberikan pelayanan kepada wisatawan dengan tidak menghilangkan budaya masyarakat di Bali yang mengutamakan keramah-tamahan, dan dalam membentuk atraksi wisata baru yang lebih unik dengan menggabungkan atraksi wisata alam dan budaya yang dimiliki Desa Visesa Resort and Villa. Hal tersebut harus dilakukan mengingat perkembangan dalam bidang pariwisata terjadi secara terus menerus sehingga diperlukan ide-ide baru yang mampu untuk menarik kunjungan wisatawan khususnya ke Desa Visesa 
Resort and Villa dan umumnya ke Bali untuk meningkatkan devisa Negara. Selain itu Desa Visesa Resort and Villa harus memperbaharui website perusahaan yang dimiliki dengan informasi yang lebih detail dengan galeri foto yang lebih menarik serta menambahkan informasi mengenai harga paket wisata yang lebih lengkap yang disertai dengan gambar kegiatan yang menarik.

Bagi agen perjalanan agar membuka kerjasama dengan Desa Visesa Resort and Villa, mengingat Desa Visesa Resort and Villa masih tergolong sebagai destinasi wisata baru yang ada di Bali sehingga agen perjalanan bisa memberikan informasi kepada wisatawan yang akan menggunakan jasanya dan akan mempercayai agen perjalanan sebagai pengatur kegiatan wisata selama berlibur di Bali.

Studi ini tentunya memiliki kelemahan terkait dengan berbagai aspek yang diteliti. Maka dari itu, untuk kedepannya disarankan kepada peneliti lain agar melakukan studi mengenai keputusan wisatawan mancanegara dalam membeli sebuah paket wisata berupa aktivitas wisata yang ditawarkan di Desa Visesa Ubud Resort and Villa, mengingat pada saat ini di Bali sedang mengalami perkembangan dalam membentuk berbagai atraksi wisata baru dengan berbagai keunikan yang dimiliki. 


\section{Kepustakaan}

Abraham H. Maslow. 1943. A Theory of Human Motivation. Psychological Review, Vol. 50, No. 4, July 1943.

Fandeli, Chafid. 1995. Dasar-Dasar Manajemen Kepariwisataan Alam. Yogyakarata : Liberty Offset.

Fauzi, Muhamad, Metode Penilitian Kuantitatif (sebuah pengantar), Semarang : Walisongo press, 2009.

Furrer, Liu, \& Sudharshan. 2001. The Relationship between culture and service quality perceptions- basic for cross- cultural market segmentation and resource allocation, Jurnal of Service Research.

Inskeep, Edward.1991. Tourism Planning And Suistainable Development Approach. New York : Van Nostrand Reinblod.
Middleton, Victor, T.C. 2001. Marketing in Travel and Tourism, Butterworth-Heinemann, London.

Pitana I Gede dan Putu G. Gayatri. 2005. Sosiologi Pariwisata, Kajian Sosiologis Terhadap Struktur, Sistem dan Dampak-dampak Pariwisata. Yogyakarta: Andi Offset.

Seaton, A.V. \& Bennet. 1996. The Marketing of Tourism Products: Concepts, Issues, and Cases. London: International Thomson Business Press.

Sugiyono. 2011. Metode Penelitian Kuantitatif, Kualitatif dan $R \& D$. Bandung : Afabeta

Wibisono, Jeffrey. 2013. Motivasi Berwisata dan Faktor Penariknya. 